\title{
Politik Hukum Terhadap Qanun Nomor 6 Tahun 2014 Tentang Hukum Jinayah
}

\author{
Rahmiati \\ Program Magister Ilmu Hukum Universitas Padjadjaran, Bandung, Indonesia \\ E-mail: rahmiati1993@yahoo.com
}

\begin{abstract}
One of the provinces that get a portion of special autonomy is the province of Aceh. Privilege in Aceh include organizing the life of religion, culture, education, and the role of the clergy in the determination of regional policy. Laws enacted in Aceh is a law which is based on the teachings of Islam, namely: Syari teachings "at Islam which further implemented in Qanun. The people of Aceh in a fairly long history has made Islam as a way of life and part of the Acehnese people. One application of Islamic law in force in Aceh today is arranged in the form of Qanun. Qanun is the rule in the region, especially in Aceh, butbefore a Qanun will be set to qanuns official, would be a debate about whether or not Qanun is to be ratified. Feasibility will be tested politically through the involvement of community members to provide feedback, comments and suggestions for improvements to a bylaws. This process is called the politics of law.
\end{abstract}

Keywords: Politics Of Law; Qanun; Jinayah Law.

\section{A. PENDAHULUAN}

Hukum diciptakan oleh manusia untuk mengatur kehidupan manusia itu sendiri demi terciptanya ketertiban, keserasian, dan ketentraman dalam pergaulan masyarakat. Menurut Soekanto hukum setidaknya mempunyai 3 (tiga) peranan dalam masyarakat, yakni, pertama, sebagai sarana pengendalian sosial; kedua, sebagai sarana untuk memperlancar proses interaksi sosial; ketiga, sebagai sarana untuk menciptakan keadaan tertentu. ${ }^{1}$

Konstitusi Negara Kesatuan Republik Indonesia, Undang-Undang Dasar 1945 mengamanatkan bahwa sistem Pemerintahan Negara Kesatuan Republik Indonesia haruslah mengakui dan menghormati satuan-satuan pemerintah daerah yang bersifat khusus atau istimewa dengan pemberian otonomi khusus, agar pemerintah daerah lebih leluasa mengatur dan mengelola pemerintahannya sendiri untuk mewujudkan kesejahteraan masyarakat. $^{2}$

Salah satu provinsi yang mendapat porsi otonomi khusus adalah Provinsi Aceh.

${ }^{1}$ Syarani, Riduan. (2004). Rangkuman Intisari Ilmu Hukum. Bandung: Citra A ditya Bakti, h. 7

${ }^{2}$ Herdiyanti, Sherly. (2015). Penerapan Sanksi Pidana Cambuk Terhadap Pelanggaran “qanun” di Bidang Maisir, Skripsi Universitas Hasanuddin, h. 4 
Keistimewaan yang dimiliki Aceh meliputi penyelenggaraan kehidupan bergama, adat, pendidikan,serta peranan ulama dalam penetapan kebijakan daerah. Hukum yang diberlakukan di Aceh adalah hukum yang bersumber pada ajaran agama Islam,yaitu, ajaran Syarieeat Islam yang selanjutnya di Implementasikan dalam Qanun. ${ }^{3}$ Masyarakat Aceh didalam sejarahnya yang cukup panjang telah menjadikan Islam sebagai pedoman hidup dan bagian dari kehidupan masyarakat Aceh. Salah satu penerapan hukum islam yang berlaku di Aceh saat ini adalah hukum cambuk. ${ }^{4}$

Sebelum suatu qanun yang akan ditetapkan menjadi qanun yang resmi, tentunya akan terjadi perdebatan mengenai layak atau tidaknya qanun tersebut untuk disahkan. Kelayakannya akan diuji secara politik melalui keterlibatan berbagai komponen masyarakat untuk memberikan tanggapan, kritik dan saran bagi penyempurnaan terhadap suatu qanun. Proses ini disebut dengan politik hukum. Politik hukum di Aceh tentu saja berbeda dengan politik hukum dengan daerah lainnya, kondisi ini dipengaruhi oleh perbedaan latar belakang kesejarahan, pandangan hidup, sosio kultural dan political will dari masing-masing pemerintah daerah ${ }^{5}$

Ketika suatu qanun sudah disahkan sebagai aturan, maka proses hukum akan dijalankan oleh pihak penegak hukum. Kebijakan dalam qanun jinayah dengan adanya hukuman cambuk sebagai sanksi terhadap pelanggar qanun tentang khalwat. Namun dalam kenyataanya wewenang yang terdapat dalam qanun jinayah itu sendiri menimbulkan adanya ketidakpastian hukum dengan adanya wewenang tentang khalwat juga diatur dalam Lembaga pembinaan adat istiadat aceh. Sehingga ini menarik untuk dikaji.

Berdasarkan uraian latar belakang di atas maka penulis tertarik untuk mengkaji permasalahan yang dikaji: "Bagaimana politik hukum qanun jinayah nomor 6 tahun 2014 tentang hukum jinayah khususnya tentang khalwat ?, dan Bagaimana wewenang yang diberikan oleh qanun jinayah nomor 6 tahun 2014 tentang khalwat ?"

\section{B. PEMBAHASAN}

\section{Tinjauan Umum Mengenai Politik Hukum Dalam Perkara Khalwat}

\section{a. Politik Hukum}

Moh. Mahfud MD mengatakan politik hukum adalah legal policy atau arah hukum yang akan diberlakukan oleh negara untuk mencapai tujuan negara yang bentuknya dapat berupa pembuatan hukum baru dan penggantian hukum lama. Lebih rinci Moh. Mahfud MD membagi 3 (tiga) kelompok politik hukum, yaitu: pertama, arah resmi tentang hukum yang akan diberlakukan (legal policy) guna mencapai tujuan negara yang mencakup penggantian hukum lama dan pembentukan hukum-hukum yang baru sama sekali; kedua, latar belakang politik dan sub-sistem kemasyarakatan lainnya dibalik lahirnya hukum, termasuk arah resmi tentang hukum yang akan atau tidak akan diberlakukan; dan ketiga, persoalan-persoalan disekitar penegakan hukum, terutama implementasi atas politik hukum yang telah digariskan. Pijakan yang menjadi landasan dari politik hukum adalah mewujudkan tujuan negara dan sistem hukum dari negara yang bersangkutan dalam

3 Ibid, h. 6

4 Purnamasari, Willy. (2013). Efektifitas regulasi Hukuman Cambuk Terhadap Pelaku Tindak Pidana Minum-Minuman Keras (Khamar) dan Perjudian(Maisir) di Kota Langsa Aceh., Skripsi UIN Sunan Kalijaga, h. 7

5 Syaukani, Imam dan Thohari, A. Ahsin, (2002). Dasar-dasar Politik Hukum, Jakarta: Raja Grafindo Persada. 
konteks Indonesia 6

Menurut Yudha Bhakti Ardiwisastra politik hukum mengandung 2 (dua) sisi yang tidak terpisahkan, yaitu pertama, sebagai arahan pembuatan hukum atau legal policy lembaga-lembaga Negara dalam pembuatan hukum; dan kedua, sebagai alat untuk menilai dan mengkritisi apakah sebuah hukum yang dibuat sudah sesuai dengan kerangka pikir legal policy untuk mencapai tujuan Negara. ${ }^{7}$

Dasar pemikiran dari berbagai definisi yang seperti ini didasarkan pada kenyataan bahwa Negara kita mempunyain tujuan yang harus dicapai dan upaya untuk mencapai tujuan itu dilakukan dengan menggunakan hukum sebagai alatnya melalui pemberlakuan atau penidakberlakukan hukum-hukum sesuai dengan tahapan-tahapan perkembangan yang dihadapi oleh masyarakat dan Negara kita. ${ }^{8}$

\section{b. Tujuan dari politik Hukum Nasional}

Bila merujuk pada kalimat terakhir pengertian politik hukum nasional diatas, jelas bahwa politik hukum nasional dibentuk dalam rangka mewujudkan tujuan cita-cita ideal Negara Republik Indonesia. Tujuan itu meliputi dua aspek yang saling berkaitan: 1) sebagai suatu alat (tool) atau sarana dan langkah yang dapat digunakan oleh pemerintah untuk menciptakan suatu sistem hukum nasional yang dikehendaki; dan 2) dengan sistem hukum nasional itu akan diwujudkan cita-cita bangsa Indonesia yang lebih besar. ${ }^{9}$

Tujuan politik hukum merupakan suatu gagasan atau cita yang mengisyaratkan kepada pembentukan peraturan perundang-undangan supaya dapat menata suatu sistem hukum di Indonesia yang dapat memenuhi kebutuhan dan tujuan masyarakat, bangsa dan negara Indonesia menuju suatu masyarakat yang adil, makmur dan sejahtera berdasarkan Pancasila dan Undang-Undang dasar 1945.

Menyadari hal itu, maka tujuan umum dari politik hukum yaitu:

a) Untuk mewujudkan kepastian hukum dan keadilan dalam kehidupan bermasyarakat, berbangsa dan bernegara.

b) Untuk mewujudkan kebahagiaan dan kedamaian dalam kehidupan bermasyarakat, berbangsa dan bernegara.

c) Untuk mengatur ketertiban dan ketentraman dalam kehidupan bermasyarakat, berbangsa dan bernegara.

d) Untuk mewujudkan kesederhanaan hukum, kesatuan hukum dan pembaharuan hukum dalam kehidupan bermasyarakat, berbangsa dan bernegara.

e) Untuk mengatur hak dan kewajiban dalam pemenuhan kebutuhan dasar manusia secara teratur sesuai dengan hak asasi manusia.

f) Untuk menjamin terpenuhinya nilai-nilai dasar yang terkandung dalam Pancasila dan Pembukaan UUD 1945.

g) Untuk menjamin perlindungan, penghormatan, pemajuan, kepastian dan keadilan dalam pemenuhan hak asasi manusia.

h) Untuk menjamin terbentuknya suatu kekuasaan negara secara demokratis dan konstitusional.

${ }^{6}$ MD, Moh. Mahfud. (2006). Membangun Politik Hukum, Menegakkan Konstitusi, Jakarta: Pustaka LP3ES, h. 5.

7 Ardiwisastra, Yudha Bhakti. (2010). Politik Hukum Lanjut, Course Material (IV) Dalam Mata Kuliah Politik Hukum Lanjut pada Program Doktor Hukum UNPAD Bandung, h 1-3.

${ }^{8}$ MD, Mahfud. Op, Cit, h. 2-3

9 Syaukani, Imam dan A Ahsin Thohari. (2005). Dasar - Dasar Politik Hukum, Jakarta: RajaGrafindo, h. 59 
i) Untuk menentukan struktur dan pembagian dan pembatasan kekuasaan negara secara seimbang dan konstitusional.

j) Untuk menetapkan bentuk, isi, dan arah dari setiap peraturan perundangundangan yang berlaku di Indonesia.

k) Untuk mewujudkan suatu negara yang dapat melindungi segenap bangsa dan seluruh tumpah darah Indonesia, memajukan kesejahteraan umum, mencerdaskan kehidupan bangsa, dan untuk ikut melaksanakan ketertiban dunia yang berdasarkan Kemerdekaan dan Perdamaian Abadi serta Keadilan Sosial.

Setiap tujuan politik hukum harus tercermin dalam berbagai materi muatan atau isi pokok dari peraturan perundang-undangan sesuai dengan bidang yang diaturnya, sebagaimana yang terjelma dalam berbagai pasal pasalnya. Disamping itu setiap materi muatan peraturan perundang-undangan yang berada di bawah Undang-Undang Dasar 1945 harus konsisten dengan peraturan yang berada di atasnya dan peraturan lainnya, baik secara vertikal maupun secara horizontal. ${ }^{10}$

\section{c. Khalwat}

Menurut bahasa, istilah khalwat berasal dari Khulwah dari akar kata khala yang berarti "sunyi" atau "sepi". Sedangkan menurut isltilah, khalwat adalah keadaan seseorang yang menyendiri dan jauh dari pandangan orang lain. Dalam pemakaiannya, istilah ini berkonotasi ganda, positif dan negatif. Dalam makna positif, khalwat adalah menarik diri dari keramaian dan menyepi untuk mendekatkan diri kepada Allah. Sedangkan dalam arti negatif, khlawat adalah perbuatan berdua-duaan ditempat sunyi atau terhindar dari pandangan orang lain antara seorang pria dan seorang wanita yang bukan muhrim dan tidak terikat perkawinan. ${ }^{11}$

Makna khalwat yang dimaksud dalam pembahasan ini adalah makna yang kedua (negatif). Khalwat dilarang Islam karena perbuatan ini bisa menjerumuskan orang kepada zina, yakni hubungan intim diluar perkawinan yang sah. Larangan zina tersebut terdapat dalam Al-quran surat Al-Isra" ayat 32:Artinya: "Dan janganlah kamu mendekati zina, karena sesungguhnya zina itu perbuatan keji dan seburuk-buruk cara."34 (Q.S. Al-Israe": 32)

Islam dengan tegas melarang melakukan zina, sementara khalwat merupakan salah satu jalan atau peluang untuk terjadinya zina, maka khalwat juga termasuk salah satu jarimah (perbuatan pidana) dan diancam dengan "uqubat ta'zir", artinya negara atau pemerintah harus berjaga-jaga untuk mengantisipasi terjadinya perzinaan. Agar tidak terjadi perzinaan salah satu usaha adalah adanya larangan khalwat. Walaupun larangan khalwat terkait dengan larangan perbuatan zina, maka tidak berarti kalau tidak melakukan zina lalu khalwat dibenarkan. Larangan khalwat sudah menjadi delik sendiri, yang tidak ada kaitannya dengan delik lain. Larangan seperti ini diberlakukan dalam masyarakat baik masyarakat modern, maupun masyarakat bersahaja. ${ }^{12}$

Hikmah diharamkannya khalwat dalam Islam adalah karena khalwat merupakan salah satu sarana yang mengantarakan kepada perbuatan zina, sebagaimana mengumbar

10 Anonym, Tujuan Politik hukum https://agroedupolitan.blogspot.co.id/2017/03/tujuan-politikhukum.html

11 Al-Yasa, Abubakar. (2011). Hukum Pidana Islam Di Aceh, Cet-2, Banda Aceh: Dinas Syarieat Islam Aceh, h. 111

12 Al Faruqi, Ahmad. (2011). Qanun Khalwat: Dalam Pengakuan Hakim Mahkamah Syar"iyah, Cet-1, Banda Aceh: Global Education Institute, h. 41 
pandangan merupakan awal langkah yang akhirnya mengantarkan pada perbuatan zina. Oleh karena itu bentuk khalwat yang dilakukan oleh kebanyakan pemuda-pemudi sekarang ini meskipun jika ditinjau dari hakikat khalwat itu sendiri bukanlah khalwat yang diharamkan, namun jika ditinjau dari fitnah yang timbul dari akibat khalwat tersebut maka hukumnya adalah haram. Para pemuda-pemudi yang berdua-duaan tersebut telah jatuh dalam hal-hal yang haram lainnya seperti saling memandang antara satu dengan yang lainnya, sang wanita mendayu-dayukan suaranya dengan menggoda, belum lagi pakaian sang wanita yang tidak sesuai dengan syarieeat, dan lain sebagaianya yang jauh lebih parah. Khalwat yang asalnya dibolehkan ini namun jika tercampur dengan hal-hal yang haram ini maka hukumnya menjadi haram. Khlawat yang tidak aman dari munculnya fitnah maka hukumnya akan tetap haram

\section{Politik Hukum dalam Qanun Jinayah Nomor 6 Tahun 2014 tentang Hukum jinayah}

Qanun Aceh adalah peraturan perundang-undangan sejenis peraturan daerah provinsi yang mengatur penyelenggaraan pemerintahan dan kehidupan masyarakat Aceh. Definisi qanun ini memberikan pemahaman bahwa qanun di Aceh terdiri atas dua kategori yaitu qanu yang mengatur materi penyelenggaraan pemerintah dan qanun yang mengatur materi penyelenggaraan kehidupan masyarakat Aceh. Qanun syariat termasuk dalam kateggori qanun yang berkaitan dengan penyelenggaraan kehidupan masyarakat. Dalam konteks peraturan perundang-undangan di Aceh, semua produk perundangundangan yang dibentuk bersama eksekutif dan legislatif (Gubernur dan DPRA) semuanya disebut qanun Aceh. Namun qanun Aceh yang berkaitan dengan syariat memiliki kekuasaan dan perbedaan dengan qanun yang berkaitan dengan pemerintahan atau dengan peraturan daerah pada umumnya. Dalam materi jinayah (pidana), qanun Aceh dikecualikan untuk mengatur ancaman pidana kurungan enam bulan dan/atau denda Rp. 50.000.000,demikian pula dengan upaya pembatalan terhadap qanun Aceh yang bermateri kinayah tidak dapat dibatalkan melalui perpres, tetapi harus melalui mekanisme uji materil mahkamah agung. Atas dasar kekhususan itulah, maka qanun Aceh berwewenang mengatur hukum cambuk bagi pelaku jinayah. Rumusan hukum cambuk yang diatur dalam qanun merupakan hasil ijtihad dan telah menjadi hukum positif nasional, sehingga dalam pelaksanaannya memerlukan kekuasaan negara melalui aparat penagak hukum yaitu polisi, jaksa, hakim dan advokat. ${ }^{13}$

Qanun nomor 6 tahun 2014 tentang hukum jinayah, didalam pasal 1 ayat (23) disebutkan bahwa Khalwat adalah perbuatan berada pada tempat tertutup atau tersembunyi antara 2 (dua) orang yang berlainan jenis kelamin yang bukan Mahram dan tanpa ikatan perkawinan dengan kerelaan kedua belah pihak yang mengarah pada perbuatan Zina. ${ }^{14}$ pengaturan tentang Khalwat terdapat didalam Pasal 23 sebagai berikut: ${ }^{15}$

(1) Setiap Orang yang dengan sengaja melakukan Jarimah khalwat, diancam dengan "Uqubat Ta'zir" cambuk paling banyak 10 (sepuluh) kali atau denda paling banyak 100 (seratus) gram emas murni atau penjara paling lama 10 (sepuluh) bulan.

(2) Setiap Orang yang dengan sengaja menyelenggarakan, menyediakan fasilitas

13 Kedudukan Syariat Islam di Aceh dalam Sistem Hukum Indonesia Kanun Jurnal Ilmu Hukum Hasan Basri http://www.jurnal.unsyiah.ac.id/kanun/article/viewFile/6253/5157

14 Pasal 1 ayat 23, Qanun nomor 6 tahun 2014 tentang hukum jinayah

15 Pasal 23 Qanun nomor 6 tahun 2014 tentang hukum jinayah 
atau mempromosikan Jarimah khalwat, diancam dengan 'Uqubat Ta'zir cambuk paling banyak 15 (lima belas) kali dan/atau denda paling banyak 150 (seratus lima puluh) gram emas murni dan/atau penjara paling lama 15 (lima belas) bulan.

Politik hukum dalam qanun jinayah menyangkut tentang khalwat adanya adanya kebijakan pemerintah daerah dalam merumuskan sanksi terhadap orang yang melanggar qanun jinayah tentang hukum jinayah khususnya pelaku khalwat. Dalam hal ini dapat kita lihat kebijakan pemerintah daerah menerapkan sanksi hukum cambuk bagi pelaku khalwat. Bentuk ancaman hukuman cambuk dimaksudkan sebagai upaya memberi kesadaran pada pelaku dan sekaligus menjadi peringatan bagi masyarakat agar tidak melakukan perbuatan yang dilarang dalam Qanun Aceh, disamping itu hukuman cambuk sebagai upaya pendidikan dan pembinaan, sehingga si pelaku akan menyadari dan menyesali kesalahan yang dilakukannya. Pelaksanaan hukuman cambuk di depan umum dimaksudkan sebagai upaya preventif dan lebih efektif karena terpidana merasa malu dan tidak menimbulkan resiko pada keluarganya. Jenis hukuman cambuk juga menjadikan biaya yang harus ditanggung oleh pemerintah lebih murah dibandingkan dengan jenis hukuman lainnya seperti yang dikenal dalam sistem KUHP yang berlaku sekarang ini. ${ }^{16}$

Meskipun Pemerintah Aceh memiliki hak dalam mengatur daerahnya secara otonom berdasarkan UU Pemerintahan Aceh, namun patut diingat bahwa kebijakan yang dihasilkan tidak dapat bertentangan dengan Konstitusi dan kebijakan nasional lainnya. Pasal 1 angka 8 UU No. 18 Tahun 2001 tentang Otonomi Khusus Bagi Provinsi Daerah Istimewa Aceh Sebagai Provinsi Nanggroe Aceh Darussalam menyatakan Qanun Provinsi NAD adalah peraturan daerah sebagai pelaksanaan undang-undang di wilayah Provinsi NAD. Hal itu diperkuat dengan Penjelasan Pasal 7 ayat (2) a UU No. 11 tahun 2012, yang mengatakan bahwa, termasuk dalam jenis peraturan daerah provinsi adalah Qanun yang berlaku di Aceh. ${ }^{17}$

\section{Wewenang yang diberikan oleh Qanun Jinayah nomor 6 Tahun 2014 tentang hukum jinayah khususnya Khalwat}

Wewenang yang diberikan oleh qanun tersebut seharusnya mencerminkan adanya kepastian hukum, kemamfaatan dan keadilan yang sesuai dengan tujuan hukum itu sendiri, wewenang merupakan upaya untuk menerapkan kaidah-kaidah hukum jinayah kepada pihak-pihak yang melanggar qanun yang telah disahkan oleh pemerintah (eksekutif dan legeslatif). Dengan demikian dapat ditegaskan bahwa qanun jinayah tersebut sebagai 'payung hukum masyarakat Aceh'. Dengan demikian, qanun jinayah itu bukan semata milik pemerintah tetapi juga milik masyarakat, dan karenanya dalam implementasinya menjadi tanggung jawab secara kolektif ${ }^{18}$ namun wewenang yang diberikan oleh qanun nomor 6 tahun 2014 tentang hukum jinayah malah tidak adanya singkroniasasi dengan adanya pasal 23 dan pasal 24. Didalam pasal 23 disebutkan:

(1) Setiap Orang yang dengan sengaja melakukan Jarimah khalwat, diancam dengan 'Uqubat Ta'zir cambuk paling banyak 10 (sepuluh) kali atau denda paling banyak 100 (seratus) gram emas murni atau penjara paling lama 10

\footnotetext{
${ }^{16}$ Ablisar, Madiasa. (2014). Relevansi Hukuman Cambuk Sebagai Salah Satu Bentuk Pemidanaan Dalam Pembaharuan Hukum Pidana, Jurnal Dinamika Hukum, h. 281

${ }^{17}$ Dikutip dari Rilis media Jaringan Masyarakat Sipil untuk Advokasi Qanun Jinayat, 22 Oktober 2017, "Desak Pemerintah untuk Meninjau Ulang Qanun Jinayat Pasca 3 Tahun pengesahan. icjr.or.id/desakpemerintah-untuk-meninjau-ulang-qanun-jinayat-paca-3-Tahun-pengesahan-//, diakses 7 Maret 2018.

${ }^{18}$ M, Soetardji. (2010). “PenempataWH Salah Kamar”, Serambi Indonesia, h. 22.
} 
(sepuluh) bulan.

(2) Setiap Orang yang dengan sengaja menyelenggarakan, menyediakan fasilitas atau mempromosikan Jarimah khalwat, diancam dengan 'Uqubat Ta'zir cambuk paling banyak 15 (lima belas) kali dan/atau denda paling banyak 150 (seratus lima puluh) gram emas murni dan/atau penjara paling lama 15 (lima belas) bulan. Dalam hal ini wewenag mengadili para pelanggar khawat akan di kenakan sanksi sesuai yang telah diatur dalam qanun. Tetapi Didalam pasal 24 Jarimah khalwat yang menjadi kewenangan peradilan adat diselesaikan menurut ketentuan dalam Qanun Aceh tentang pembinaan kehidupan adat dan adat istiadat dan/atau peraturan perundang-perundangan lainnya mengenai adat istiadat.

Hal ini menjadi menarik karena mengenai wewenang dalam mengadili pelanggar qanun jinayah di Aceh, adanya penguatan untuk memberlakukan proses penyelesaian qanun jinayah melalui peradilan adat. Peradilan adat adalah peradilan proses menerima, memeriksa, mengadili, dan menyelesaikan menurut kebiasaan daerah tertentu (Anonimous, 2003: 6). Indikasi ini dapat diketahui dari ditetapkannya Qanun Aceh Nomor 10 Tahun 2008 tentang Lembaga Adat. Kewenangan yang dijalankan lembaga adat diatur dalam Pasal 4,"dalam menjalankan fungsinya, sebagaimana dimaksud dalam Pasal 2 ayat (1) lembaga adat berwenang :

a) menjaga keamanan, ketentraman, kerukunan, dan ketertiban masyarakat;

b) membantu pemerintah dalam melaksanakan pembangunan;

c) mengembangkan dan mendorong partisipasi masyarakat;

d) menjaga eksistensi dan nilai-nilai adat dan adat istiadat yang tidak bertentangan dengan syari'at Islam;

e) menerapkan ketentuan adat

f) menyelesaikan masalah sosial kemasyarakatan;

g) mendamaikan sengketa yang timbul dalam masyarakat;

h) menegakkan hukum adat.

Selain itu, Pemerintah Aceh juga telah mengesahkan Qanun No. 9 Tahun 2008 tentang Pembinaan Kehidupan Adat dan Adat Istiadat. Pada Bab VI mengenai Penyelesaian Sengketa perselisihan seperti yang termuat dalam Pasal 13, setidaknya terdapat 18 (delapan belas) sengketa yang menjadi perhatian khusus dalam pembinaan adat dan adat istiadat ini yaitu:

1) perselisihan dalam rumah tangga;

2) sengketa antara keluarga yang berkaitan dengan faraidh;

3) perselisihan antar warga;

4) khalwat mesum;

5) perselisihan tentang hak milik;

6) pencurian dalam keluarga (pencurian tangan);

7) perselisihan hareuta seuhareukat;

8) pencurian ringan;

9) pencurian ternak peliharaan;

10) pelanggaran adat tentang ternak, pertanian, dan hutan;

11) persengketaan di laut;

12) persengketaan di pasar;

13) penganiayaan ringan;

14) pembakaran hutan (dalam skala kecil yang merugikan komunitas adat);

15) pelecehan, fitnah, hasut, dan pencemaran nama baik; 
16) pencemaran lingkungan (skala ringan);

17) ancam mengancam (tergantung dari jenis ancaman)

18) perselisihan-perselisihan lain yang melanggar adat dan adat istiadat;

Kewenangan yang diberikan qanun Nomor 10 Tahun 2008 tentang Lembaga Adat, sepertinya sangat umum dan memungkinkan lahirnya multi tafsir terhadap bentuk dan sifat kewenangan yang dilakukan. Kaitannya dengan qanun jinayah, seperti qanun khalwat sepertinya ini terdapat kejanggalan dalam sistem hukumnya. Satu sisi, mengenai pengaturan khalwat sudah diatur dalam Qanun nomor 14 Tahun 2003 tentang Khlawat (Mesum). Tapi di sisi lain, qanun pembinaan adat dan adat istiadat, juga memasukkan khalwat (mesum) sebagai ranah kewenangan dalam penyelesaiannya. Berdasarkan berita yang dimuat di harian yang terbit di Aceh, hampir tiap hari ada saja pelanggaran qanun khalwat yang terjadi antara laki-laki dan perempuan yang bukan suami isteri yang sah (mahram). Tetapi kasusnya sudah jarang diajukan ke Mahkamah Syar'iyah, Berdasarkan amatan yang dilakukan selama ini, ternyata kasus khalwat banyak diselesaikan 'secara adat', baik dengan cara pembinaan atau menasehati maupun dengan menikahkan pelaku khalwat yang tertangkap tangan. Persoalannya, menikahkan pelaku khalwat bukan merupakan sanksi adat dan justru tidak ada sanksi adat berbentuk pernikahan. ${ }^{19}$

Munculnya peraturan adat sebagai instrumen untuk menyelesaikan sejumlah kasus pelanggaran jinayah di Aceh, lebih disebabkan oleh adanya wewenang yang diberikan oleh Qanun No. 9 Tahun 2008 tentang Pembinaan Kehidupan Adat dan Adat Istiadat. Sehingga dengan adanya qanun tersebut telah memberikan peluang besar bagi peradilan adat di gampong untuk menyelesaikan sejumlah kasus pelanggaran jinayah di Aceh khususnya khalwat diselesaikan secara adat setempat. Hanya saja yang membingungkan, setiap sanksi adat yang diberikan kepada pelanggar tidak ada sanksi yang sama, seperti kasus pelanggaran khalwat, pelanggarnya ada yang dinikahkan, denda dua ekor kambing, dan denda uang. Secara teoritis, adanya dua instrumen hukum untuk kasus yang sama dikenal dengan "pluralisme hukum" atau "legal pluralism" ${ }^{20}$, dalam arena pluralisme hukum itu, terdapat hukum negara di satu sisi, dan di sisi lain adalah hukum rakyat yang pada prinsipnya tidak berasal dari negara, yang terdiri dari hukum adat, agama, kebiasaankebiasaan atau konvensi-konvensi sosial lain yang dipandang sebagai hukum.

Di dalam substansi qanun-qanun jinayah masih terdapat kelemahan, baik isinya atau pasal-pasal yang terdapat di dalam qanun tersebut. Walaupun itu sebenarnya masih ada potensi bagi para penegak hukum seperti Hakim Mahkamah Syar'iyah, Kejaksaan, Polisi dan Pengacara memiliki otoritas untuk melakukan penemuan hukum, jika mengacu pada prinsip hukum positif, maka kasus seperti ini jelas tidak dapat disebut sebagai penganut mazhab hukum positif, sebab hukum yang seharusnya dilaksanakan bukan hukum adat, melainkan hukum yang tertulis dalam qanun, walaupun isi qanun jinayah tersebut mengandung kelemahan. Lebih utama lagi, bahwa posisi aparat penegak hukum sesungguhnya bukan merupakan corong hukum yang tertulis, aparat penegak hukum merupakan penemu hukum dari hukum yang kurang lengkap isinya selama tidak bertentangan dengan ketentuan hukum di atasnya. ${ }^{21}$

19 Ibrahim, Armia. (2010). Proses Hukum terhadap Pelanggaran-pelanggaran Qanun Syariat Islam, Bahan Pembekalan Qanun-Qanun Syariat Islam bagi Ulama/Tokoh Perempuan se-Kota Banda Aceh. Tanggal 27-28 April.

20 Irianto, Sulistyowati. (2005). Perempuan di Antara Berbagai Pilihan Hukum, Jakarta: Yayasan Obor, h. 28.

21 Mahdi, Sistem penegakan hukum qanun jinayah diaceh https://jurnal.arraniry.ac.id/index.php/medsyar/article/viewFile/1786/1329 


\section{P E N U T U P}

Berdasarkan hasil penelitian ini maka dapat disimpulkan bahwa politik hukum yang terdapat dalam qanun jinayah nomor 6 tahun 2014 tentang hukum jinayah adanya kebijakan dari pemerintah daerah yang menerapkan sanksi pidana cambuk bagi pelanggaran tidak pidana khalwat. Kewenangan yang terdapat dalam qanun jinayah nomor 6 tahun 2014 tentang hukum jinayah tidak adanya singkronisasi antara pasal 23 dan pasal 24, sehingga menjadi kelemahan dalam penyelesaian perkara khalwat, selain itu juga tidaknya kepastian hukum dikarenakan adanya pasal 24 qanun nomor 6 tahun 2014

\section{DAFTAR PUSTAKA}

\section{Buku}

[1] Al-Yasa, Abubakar. (2011). Hukum Pidana Islam Di Aceh, Cet-2, Banda Aceh: Dinas Syarieeat Islam Aceh.

[2] Al Faruqi, Ahmad. (2011). Qanun Khalwat: Dalam Pengakuan Hakim Mahkamah Syar"eiyah, Cet-1, Banda Aceh: Global Education Institute.

[3] Irianto, Sulistyowati. (2005). Perempuan di Antara Berbagai Pilihan Hukum, Jakarta: Yayasan Obor.

[4] MD, Moh. Mahfud. (2006). Membangun Politik Hukum, Menegakkan Konstitusi, Jakarta: Pustaka LP3ES.

[5] Syaukani, Imam danThohari, A. Ahsin, Dasar-dasar Politik Hukum, Jakarta: Raja Grafindo Persada, 2002.

[6] Syarani, Riduan. (2004). Rangkuman Intisari Ilmu Hukum. Bandung: Citra A ditya Bakti.

[7] Syaukani, Imam dan Thohari, A. Ahsin. (2005). Dasar-Dasar Politik Hukum, Jakarta: RajaGrafindo.

\section{Jurnal dan Lain-Lain}

[8] Ardiwisastra, Yudha Bhakti. (2010). Politik Hukum Lanjut, Course Material (IV) Dalam Mata Kuliah Politik Hukum Lanjut pada Program Doktor Hukum UNPAD Bandung.

[9] Ablisar, Madiasa. (2014). Relevansi Hukuman Cambuk Sebagai Salah Satu Bentuk Pemidanaan Dalam Pembaharuan Hukum Pidana, Jurnal Dinamika Hukum

[10] Herdiyanti, Sherly. (2015). Penerapan Sanksi Pidana Cambuk Terhadap Pelanggaran "qanun" di Bidang Maisir, Skripsi Universitas Hasanuddin.

[11] Ibrahim, Armia. (2010). Proses Hukum terhadap Pelanggaran-pelanggaran Qanun Syariat Islam, Bahan Pembekalan Qanun-Qanun Syariat Islam bagi Ulama/Tokoh Perempuan se-Kota Banda Aceh. Tanggal 27-28 April. 
[12] Purnamasari, Willy. (2013). Efektifitas regulasi Hukuman Cambuk Terhadap Pelaku Tindak Pidana Minum-Minuman Keras (Khamar) dan Perjudian(Maisir) di Kota Langsa Aceh., Skripsi UIN Sunan Kalijaga

[13] Anonym, Tujuan Politik hukum https://agroedupolitan.blogspot.co.id/2017/03/tujuan-politik-hukum.html.

[14] Dikutip dari Rilis media Jaringan Masyarakat Sipil untuk Advokasi Qanun Jinayat, 22 Oktober 2017, "Desak Pemerintah untuk Meninjau Ulang Qanun Jinayat Pasca 3 Tahun pengesahan. icjr.or.id/desak-pemerintah-untuk-meninjau-ulang-qanunjinayat-paca-3-Tahun-pengesahan-//, diakses 7 Maret 2018.

[15] Kedudukan Syariat Islam di Aceh dalam Sistem Hukum Indonesia Kanun Jurnal Ilmu Hukum Hasan Basri http://www.jurnal.unsyiah.ac.id/kanun/article/viewFile/6253/5157

[16] Mahdi, Sistem penegakan hukum qanun jinayah diaceh https://jurnal.arraniry.ac.id/index.php/medsyar/article/viewFile/1786/1329 